\title{
Ecology and Afforestation
}

$\mathrm{T}$ HE symposium at Cambridge on "The Cultivation of British Hardwoods" (Department of Forestry, $\mathrm{K}^{*}$ ) and the papers on "The Ecological Aspects of Afforestation" (Section K (Botany) and Department of Forestry, K*) brought out clearly on $\theta$ point of great practical and scientific importance. It is the need for distinguishing between woodland and non-woodland environments.

Since it is the policy of the Government to add to the existing area of woodlands, it follows that most of the new planting is carried out on soils which bear a kind of vegetation other than woodland, and it is just on this class of soil and under the conditions associated with it that difficulties are experienced in the establishment of hardwoods. Many, if not all, the soils of Great Britain presumably once carried some kind of woodland, but the land has been cleared and put to various uses or misuses. Most of it has been farmed and still is, but at various times some of it has been allowed to run wild. This marginal land is commonly heavy clay or light sand, and its abandonment is usually attributed to falling prices of major farm produce. Doubtless this is a main cause; but it may well be questioned whether modern farming methods, by destroying the physical and biological regime of the woodland soil, have not been a potent contributory cause. Besides the farm land carved from the original forest, there are the wide open spaces of heather, peat or poor grassland to which the forest failed to return because of regeneration difficulties due in the main to grazing, burning, or the lack of parent trees. Under these conditions, too, the forest soil has been altered : in fact the set of conditions associated with a complex biological unit and built up slowly by Nature has been destroyed, or degraded from its woodland status.

The problem stated affords an excellent illustration how the larger light emanating from the study of plant communities in general can be usefully focused upon the practical problems of the forester. For to the ecologist the forest is not merely a collection of trees with a certain density and rate of growth : it is also a community of organisms living together in a more or less intimate and intricate relationship. This forest biological unit is achieved only after much preparation in Nature during the sequence of changes separating the early stages of the plant succession from the later, culminating generally, in the climate of Great Britain, in woodland. It thus becomes easier to understand why trees like oak and beech, which normally appear late in the succession, are difficult to establish on new ground, for the conditions of microclimate and soil (including microflora and microfauna) under which they become established in Nature are widely different from those offered by marginal and waste land. Further, it is well for the forester to realize that in planting he is not only planting to produce timber but he is also setting in train a whole series of processes culminating in the formation of a complex biological unit.

Conifers are less exacting than hardwoods and can be more readily established on land available for planting, and Prof. H. M. Steven in his paper on "The Ecological Aspects of Afforestation in Hill Country" touched on their use as pioneer crops. He said that although vegetation may be a safe guide in the selection of species which will readily become established, it need not necessarily be correlated with the subsequent growth of the trees after they have formed canopy. Here, one can assume that the forest, so to speak, takes charge and changes the environment, so that the coniferous crops now being established may be looked on as catch crops ameliorating the conditions for more exacting species to follow. The same points emerged in Mr. R. Ross's account of the colonization by hawthorn of abandoned arable land in the heavy chalky boulder clay district of west Cambridgeshire: under the hawthorn scrub the soil changes in the direction of a woodland soil in acquiring more humus and an open crumb structure.

A pioneer coniferous crop mostly of pines has been successfully established by the Forestry Commission in Breckland, an area with climate transitional between oceanic and continental and much subject to spring frosts, with open permeable soils incapable of holding much water against shortage during drought and with a chalk content which varies from soils with much, through soils deficient in it, to those completely devoid of it. The last type is extremely infertile. Dr. A. S. Watt gave a summary of his work on the area and concluded that liability to frost, shortage of water and plant nutrients are the critical factors capable of amelioration, at least in part, through normal sylvicultural procedure. By controlling the canopy the internal climate of the woodland is ameliorated and the less hardy species can be successfully reared; by careful choice of species and by planting them in suitable proportions, the water-holding and base-holding capacities of the 
soil can be appreciably altered through the control of the amount and, more important still, the kind of humus produced.

In the subsequent discussion, Sir Roy Robinson explained that the exigencies of the moment had largely determined the selection of conifers for planting, and that it was likely that the next generation of the forest would, in certain parts of Great Britain, at least differ markedly in composition particularly by the use of more hardwoods. This is welcome news; and more followed. For
Sir Roy announced on behalf of the Forestry Commission the initiation of a programme of closer co-operation between the forester and the scientific worker, particularly the ecologist, and offered to set aside quite considerable areas in selected forests for purposes of scientific study, primarily for a periodic record of the changes in the vegetation. But many scientific interests are involved, and one may look for results fruitful to science generally as well as to the forester, from this opportunity to study a forest in the making.

\section{Limestones as Eruptive Rocks}

$\mathrm{T}$ HE carbonate-rocks, especially limestones and dolomites, are so well known as sedimentary or metamorphosed sedimentary rocks that there may be some surprise that petrologists of Section C (Geology) of the British Association spent the greater part of a day during the recent Cambridge meeting in discussing the origin of carbonate-rocks associated with alkali-rich intrusions.

The occurrence of limestones in close association with alkali-rich rocks, such as nepheline-syenites, phonolites and related types, has been observed with great frequency and it has commonly been assumed that the limestones, where not clearly belonging to a sedimentary formation, were relics of sedimentary limestones assimilated in depth by the igneous magmas.

According to a widely accepted theory proposed by R. A. Daly in 1910, such assimilation of limestone by sub-alkaline magmas is the cause of the formation of the alkali-rich igneous rocks.

However, so early as 1892, some limestones occurring in the form of dykes and cutting the volcanic rocks of the Kaiserstuhl in Baden, were described by $\mathbf{A}$. Knop, and three years later A. G. Hogböm described limestone dykes in a region of alkali-rich intrusives on the island of Alnö in Sweden. Hogböm also recorded calcite as a primary mineral in some rocks at Alnö, and there were other descriptions of primary calcite in alkalieruptive rocks from Canada and India. In view of the readiness with which calcite dissociates on heating, geologists were reluctant to accept it as a primary mineral or to believe in limestone intrusions, but during the last few years much fresh evidence of apparently intrusive carbonaterocks has been obtained.

The most convincing new evidence comes again from Alnö, where the rocks are now far better exposed than they were at the time of Hogböm's visits forty-three years ago. They have been studied thoroughly by Dr. Harry von Eckermann, of Stockholm, who opened the discussion at Cambridge. A large area of alkali-intrusivesnepheline-syenites and ijolites-cuts the Precambrian gneisses and is probably late-Jotnian in age. Around the contact with the gneiss (which is altered) crystalline limestones appear, and outside the neck of intrusive rocks there are calcitic and dolomitic dykes which are shown to be conesheets dipping towards two deep central foci. From the inclination of the cone-sheets the focus of the calcite dykes can be shown to be at 1-2 km. below the present surface, and that for the dolomitic sheets at 6-7 km. The geology of the country near Alnö is well known, and von Eckermann regards it as certain that for hundreds of miles around and to great depths there is no trace of sedimentary limestone in the Archæan rocks of earlier age than the alkali-intrusives. All the evidence points to a magmatic origin for these limestones at Alnö.

Magmatic origin is also claimed by Dr. F. Dixey for the crystalline limestone associated with breccias filling remarkable vents of post-Karroo age in Southern Nyasaland. At one of the largest of these vents, Chilwa Island, limestone and orthoclase-breccias occupy a roughly circular area $1 \frac{1}{2}$ miles across and form steep cliffs rising $1,400 \mathrm{ft}$. above the level of Chilwa Lake. Nine larger and seven smaller vents are known, and at most of them the limestones are cut by small bodies or dykes of alkali-rich rocks, nepheline-syenite, ijolite, phonolite, or nephelinite. The rocks surrounding the vents are altered and there are many resemblances with the rocks of Alnö. As for the source of the limestone, Dr. Dixey finds that the small lenticles of limestone known to occur in the Basement Complex of the district are altogether too small and infrequent to have supplied the limestone for the great masses of the Chilwa vents, and the conclusion that they are in some way magmatic seems unaroidable. 